\title{
Protein-calorie intakes of hospital patients
}

\author{
By T. P. EDDY AND P. L. PELLETT \\ Human Nutrition Department, London School of Hygiene and \\ Tropical Medicine, Keppel Street, London, WCI \\ (Received I7 April 1964-Accepted 6 July 1964)
}

Food in Hospitals, a report published by the Nuffield Provincial Hospital Trust, described the results of a study of the nutritive value of food in a survey of 152 provincial non-teaching hospitals. The hospitals were selected at random, and in each hospital the food taken by one patient on a full normal diet, also selected at random, was measured over a period of $24 \mathrm{~h}$. The methods of sampling are fully described in the published report (Platt, Eddy \& Pellett, 1963).

Much of the work done upon the protein quality of the food taken by patients in hospital was considered to be too technical for inclusion in the original report, though some of the conclusions and recommendations in the report were based upon the detailed evaluation of protein-calorie intakes. The methods used and the results obtained are now described in this paper.

\section{METHODS}

\section{Classification of patients}

According to each sampled patient's presumed need, the diets were classified into three groups: maintenance--diets for patients admitted for over 6 months, and a few others with a history of long periods in hospital for a chronic complaint, or of longstanding chronic disease; recuperative-diets for patients on short admissions for ordinary acute diseases or trauma, or for recent incidents occurring in degenerative diseases, for example, recent cardiac infarction; mental--diets for patients in hospitals for mental illness, many but not all of whom were fully active and helped with the hospital work. Excluding unweighed and 'overweight' patients, i.e. those whose weights were in excess of the highest limits given for ideal weight for a 'large frame' by the Metropolitan Life Assurance Company (1959), fifty-eight were classified for a recuperative diet, sixteen for maintenance and thirteen as mental; of the patients classified as overweight twenty-two patients were for recuperative diets, twelve for maintenance diets and seven were mental.

\section{Analysis of meals}

The chemical analysis of each meal included the determination of metabolizable energy, crude protein $(\mathrm{N} \times 6 \cdot 25)$ and sulphur. Analytical procedures including an improved method for total $\mathrm{S}$ are fully described elsewhere (Pellett \& Eddy, 1964). 
Metabolizable energy was determined by the method of Miller \& Payne (I959) using their ballistic bomb calorimeter. $N$ estimation was by a semi-micro-Kjeldahl procedure (Association of Official Agricultural Chemists, 1960). Crude protein was expressed as the total metabolizable energy that could be derived from the protein if it were all used for energy purposes, the factor of $4 \mathrm{kcal} / \mathrm{g}$ protein being used. From the resulting protein-calorie value the percentage of the total metabolizable energy contributed by the crude protein-protein $\mathrm{kcal} \%(\mathrm{PCal} \%)$-was calculated.

\section{Assessment of protein quality}

FAO $(1957 b)$ set out protein requirements in terms of reference protein, which can be defined as protein that theoretically contains $16 \% \mathrm{~N}$ and is fully utilized by the body for anabolic purposes ((USA) National Research Council, I 963 ). It is convenient to state values of reference protein in terms of the energ. that could be obtained if it were used in the body for such purposes, expressed as a fiercentage of the total energy requirements (reference protein $\mathrm{kcal} \%$ ).

A protein score giving a numerical value of protein quality may be obtained by relating the contents of essential amino acids in protein to that of FAO reference protein. Rose, Haines \& Warner (1954) considered that 'the diets consumed by a large part of the human race are relatively low in methionine'. Miller \& Donoso (1963) demonstrated that in twenty-five human diets containing mixed proteins from different sources the contents of S-containing amino acids (methionine and cystine) were the factors limiting net protein utilization (NPU), and thus the $\mathrm{S}$ amino acid content in relation to total $\mathrm{N}$ could be used as a method for determining protein score. They further found that the dietary $\mathrm{S}: \mathrm{N}$ ratio gave a good estimate of the protein score.

In the course of the survey, protein scores were calculated by two methods, both depending upon the postulate that methionine and zystine are the amino acids limiting protein quality. Firstly, from the chemical determinations of $S$ and $\mathrm{N}$ in sampled meals the score was determined as described by Miller \& Donoso from the $\mathrm{S}: \mathrm{N}$ ratio. Secondly, for all meals and all extras, the weights of S-containing amino acids per $\mathrm{g} \mathrm{N}$ were estimated by the use of food tables from the gross weights of food in each dish served to a ward at each meal and from the records of between-meal extras taken by the patients. From the resulting values, protein scores were assigned by comparison with the reference value for the S-containing amino acids in FAO reference protein.

From the protein scores and $\mathrm{PCal} \%$, it was possible to calculate protein values as net dietary protein calories \% (NDpCal \%) by the method of Platt, Miller \& Payne (I96r) and Miller \& Payne (I96r $a$ ). The net dietary protein value of food is obtained from the product of protein quantity $\times$ quality, and $s$ an expression showing the equivalent effective quantity of reference protein that can be utilized in the diet. $\mathrm{NDpCal} \%$ is generally equivalent to the expression reference protein kcal \% given above. Though it may be conveniently predicted from protein score and protein concentration by these methods, it is normally determined by biological assay as the product of NPU (operative) and PCal \%. $\mathrm{NPU}_{(\mathrm{op})}$, being the percentage of the $\mathrm{N}$ that 
is retained from a given diet, is a measure of the efficiency of utilization of dietary $\mathrm{N}$, or of protein quality.

At the end of the survey, values for over 500 homogenized meals were available; these were classified into typical types of menu (for example, fish + legume; meat + egg; porridge + meat) and subjected to biological assay of $\mathrm{NPU}_{(\mathrm{op})}$ by using the method described by Platt $e t$ al. (1961). The values of NDpCal \% so obtained were compared with the predicted values derived from protein scores obtained by both the methods described above; the correlation coefficients were found to be of the order of $0.85 \pm$ O.II (SE). This confirmed that the methods employed could be used as practical measures of protein value. The mean protein score of the bulked meals calculated from the biological determinations of $\mathrm{NPU}_{(\mathrm{op})}$ was $77^{\circ} 5$ with a standard deviation of $7^{\circ} \mathrm{O}$.

\section{Correction of predicted protein values for calorie restriction}

The values of NDpCal \% obtained by these methods are based upon the assumption that the food would be eaten without restriction by a growing animal which would use dietary protein with maximum efficiency. However, the consumer's requirements for energy are pre-eminent, so that the utilization of protein would be restricted at lower levels of calorie intake; protein would be deaminated and used to supply the needed energy, and the NPU $(\mathrm{op})$ would fall. Under these conditions the effective protein value depends upon the energy available for anabolism, rather than upon protein concentration and quality. Experimental measurements of this effect have led to the formulation of the following equation by Miller \& Payne $(\mathrm{r} 96 \mathrm{I} b)$ giving the corrected or effective NDpCal \%:

$$
\text { Effective NDpCal \% }=\frac{100}{E}\left(1-\frac{C b}{C}\right)=\frac{100}{6}\left(1-\frac{C b}{C}\right)=17\left(1-\frac{C b}{C}\right),
$$

where $C=$ kcal required for basal metabolism and $E=$ kcal required for the synthesis of $\mathrm{x}$ kcal of protein $=6 \mathrm{kcal}$ approximately.

The predicted value of NDpCal \% for the hospital diets was corrected to effective NDpCal \% by means of equation ( $\mathrm{I})$, the kcal required for basal metabolism being estimated from the tables of Robertson \& Reid (1952). The lesser of the two values was taken as the effective protein value of the diet. The equation is shown as the line $A B$ in Fig. I and its application to the sampled diets is discussed below.

\section{RESULTS}

The values of NDpCal \% as predicted from protein score and protein concentration for the sampled $24 \mathrm{~h}$ diets of patients of 'normal weight' are plotted in Fig. I in relation to their total metabolizable energy expressed as a percentage of each patient's basal metabolism. The corrected effective NDpCal \% given by the equation is shown in the figure as the line $A B$. The protein-calorie values of diets above the line $A B$ are energy-restricted and the corrected predicted value for effective NDpCal $\%$ is obtained by a reading on the line $A B$ vertically below the point plotted for each diet. It can be seen that more than half the protein values need to be corrected for energy restriction: 
all those for chronic patients allotted maintenance diets; $65 \%$ of those for acute patients allotted recuperative diets; and $50 \%$ of those for patients in hospitals for mental disease.

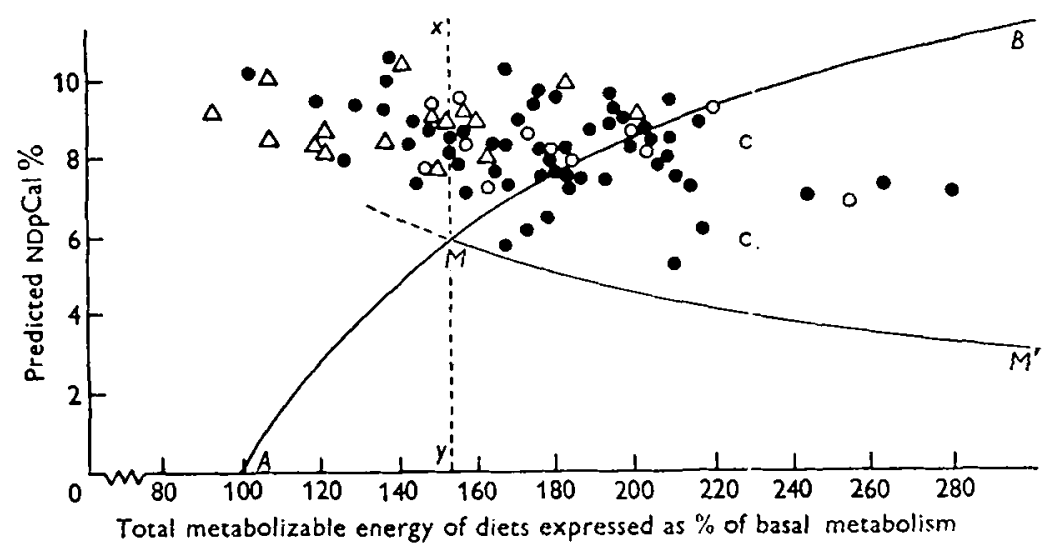

Fig. I. Unrestricted values of NDpCal \% are shown for each 24 h diet: 0 , patients in hospitals for mental illness; $\bullet$, patients requiring recuperative diets; $\Delta$, long-stay patients requiring maintenance diets.

The line $A B$ represents equation y (p. 557) giving the correc:ion for calorie restriction. At the calorie intakes shown the NDpCal \% of each diet above the line is obtained by reading from the corresponding point on $A B$ vertically below.

$M M^{\prime}$ : represents equation 2 (below) giving the protein maintunance requirement of $22.5 \mathrm{mg}$ reference protein per basal metabolic kcal. $x y$ represents the en bolism) at which $M M^{\prime}$ cuts the line $A B$. All diets plotted to the left of line $x y$ fall below the requirement for maintenance when corrected for calorie restriction.

Miller \& Payne (1962) have shown in animal feeding experiments that, over a wide range of calorie intake, the protein requirement for maintenance of body-weight can be expressed by the equation:

$$
\frac{C}{C b} \times \mathrm{NDpCal} \%=8 \cdot 9 .
$$

Equation (2) is shown on Fig. I as the line $M M^{\prime}$. It represents an intake of $22.5 \mathrm{mg}$ reference protein or net dietary protein per basal metabolic kcal. Table I gives the intake of protein calories by patients of normal weight on diets illustrated in Fig. I after corrections for energy restriction to the predicted effective values of net dietary protein had been made. In Table I the patients are grouped by age and sex, and it will be seen in the final column of the table showing mg net: dietary or reference protein/ basal metabolism kcal that only for the group of nine women over 70 years of age (some of whom were over 80 years old) was the net value lower than $22.5 \mathrm{mg}$ - the requirement for maintenance.

\section{DISCUSSION}

Miller \& Payne (1964) have described the main factors influencing the efficiency of utilization of dietary $\mathrm{N}$ upon which the protein values described in this paper have been based. The possible changes in NDpCal \% caused by these factors within the 


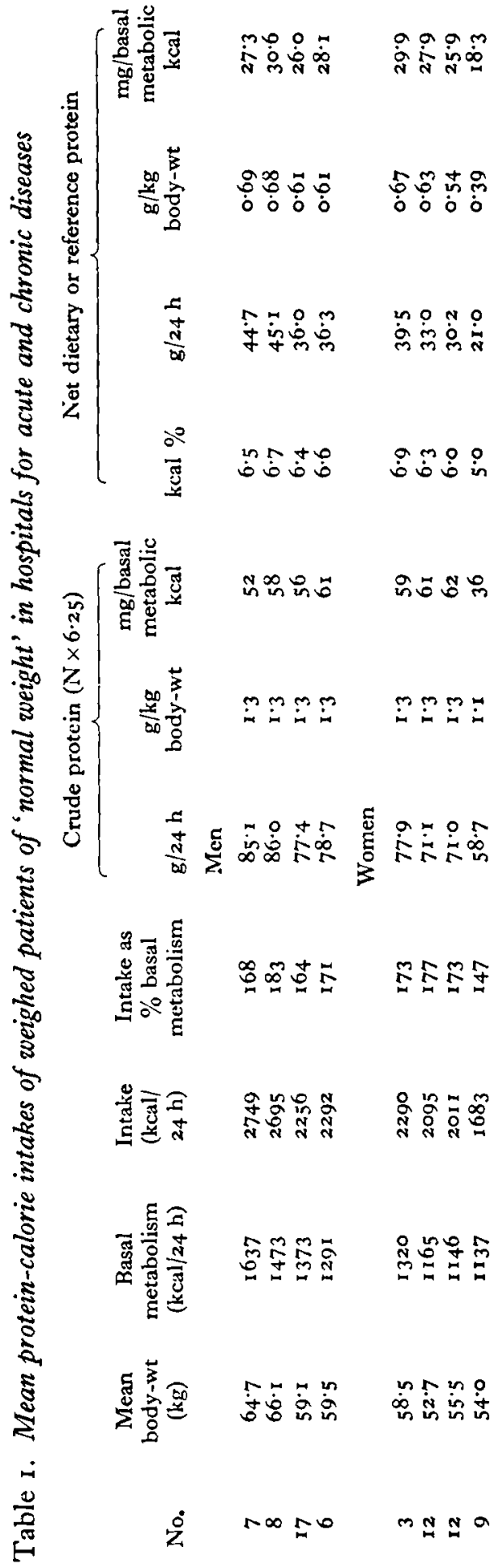

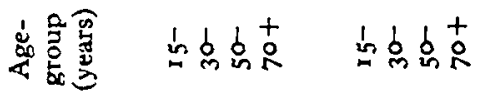


practical ranges covered by human diets are: amino acic pattern or score, twofold; protein: calorie ratio, fourfold; calorie intake, infinite (i.e. from famine to adequacy). Taking these factors into account, they concluded that a good estimate of $\mathrm{N}$ balance might be calculated from a knowledge of the composition and quality of a given diet, and that these calculations were of value when applied to groups or populations.

They proposed tentatively (Miller \& Payne, I $96 \mathrm{I} b$ ) that equation ( $\mathrm{I}$ ) could be applied to human diets. Experiments designed to deternine its applicability to man are to be undertaken, but there is already considerable evidence of its validity.

Calloway \& Spector (1954) in a review of data on $\mathrm{N}$ balance in relation to calorie and protein intakes of active young men observed that, at each fixed intake of protein, $\mathrm{N}$ balance increased with energy intake in a linear fashion up to a critical level; when energy intake was less than the critical level, $\mathrm{N}$ balance was not altered by increasing the protein intake. Regimens of this kind have beer. called 'calorie restricted', implying that energy was the limiting factor.

Swanson (1959) reviewing the influence of total ener:yy of diets on protein metabolism stated: 'Increments in food energy value permit improved utilization of food nitrogen for synthesis and conservation of body protein, but there appears to be an optimum caloric intake associated with maximum retention at various levels of dietary protein.' In a personal communication, P. R. Payne ( 1964 , unpublished) has given estimates of the factor $E$ in equation (1) using data obtair ed from the literature. These are shown in Table 2 which gives data derived from experiments with both men and rats.

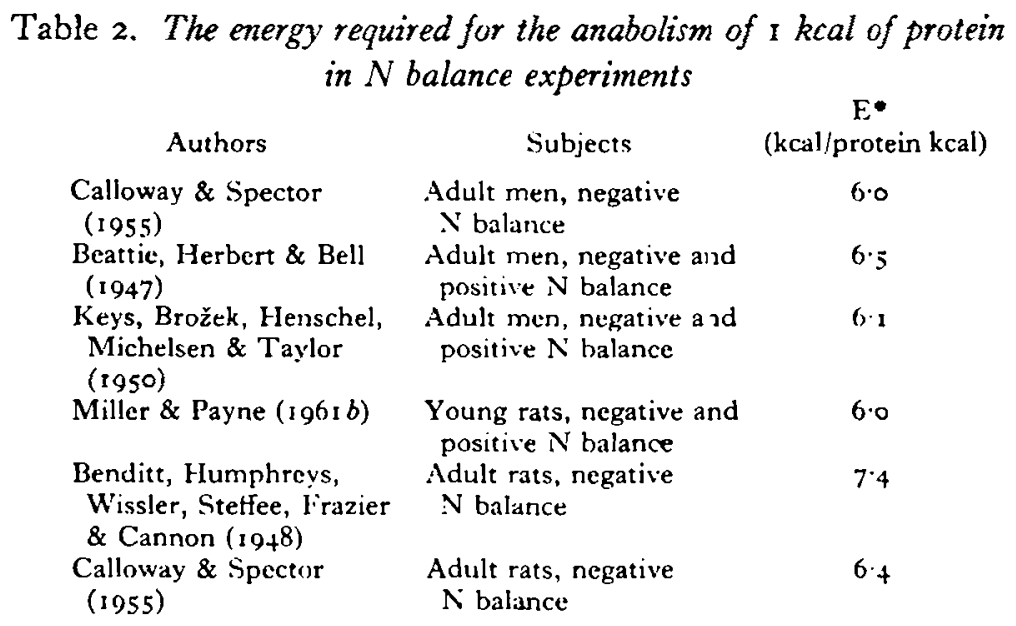

- $E$ is the constant which represents the energy required for the anabolism of one unit of protein (Miller \& Payne, 1961 $b$ ) expressed as $\mathrm{kcal} / \mathrm{protein} \mathrm{kcal}$. The table shows estimates of $E$ calculated from published data giving determinations of $N$ balance over a range 0. calorie intakes.

Three altcrnative explanations for the reduction of predicted protein-calorie values by calorie restriction in the diets illustrated in Fig. I are possible: ( 1 ) that the provision of protein in the diet was more than adequate, more than could be retained and utilized for protcin anabolism; (2) that the calorie intake was ir adequate, because of illness or lack of appetite; (3) a combination of $I$ and 2. 
Each group of diets may be considered in relation to the lines $M M^{\prime}$ and $x y$ in Fig. I. Diets for which the predicted NDpCal \% either fell below $M M^{\prime}$ or to the left of $x y$ would be expected to be inadequate for maintenance; in the latter instance they would be calorie restricted and the corrected predicted protein value would fall below the continuation of $M M^{\prime}$. The recipient would be expected to be in negative $\mathrm{N}$ balance and to lose weight.

Of the fourteen diets from hospitals for mental illness two were inadequate by these criteria, but the two points fall only just to the left of line $x y$ in Fig. I and, allowing for personal and daily variation, the diets may be said to have provided sufficient for maintenance.

About half the intakes of patients classified for maintenance diets fell below the requirement for maintenance because of calorie restriction. The mean calorie intake was $140 \%+7 \cdot 7 \%$ (sE) of basal metabolism-below but not significantly below the minimum requirement for maintenance. The basal metabolism of some of the patients may have been overestimated, but some, as a result of long-standing progressive disease, were suffering an inevitable physical decline. It should therefore not be surprising that this assessment of their diet suggests that some were in negative $\mathbf{N}$ balance.

\section{Protein requirements in recovery from illness or trauma}

The losses of protein which occur during disease or injury may amount to some hundreds of grammes, or in serious injury to a kilogramme or more. Full recovery depends upon the replacement of the lost protein and, except for the special measures of transfusion or tube-feeding, the source of the required protein will be ordinary food. In most patients, complete restoration with complete return to health will not take place in hospital; the greater part of convalescence will occur after discharge. But the recovery starts in hospital, and its speed is dependent upon good feeding.

The patients classified as in need of recuperative diets showed a wide range of calorie intakes extending from the bare requirements for basal metabolism (102 \%) to $270 \%$ of it. The mean calorie intake was $178 \% \pm 4.2 \%$ (SE) of basal metabolism. Many of the patients with calorie intakes below $150 \%$ of basal metabolism were postoperative patients, and illness or postoperative discomfort may have affected appetite; the patient with lowest intake- $102 \%$ of basal metabolism-had a traumatic laryngitis after anaesthetic intubation.

The concentration of protein is high in many of these diets. Even in this country, with its freedom from food shortage and abundant supplies of food from animal sources, clinicians are often concerned about the protein nutrition of geriatric patients and of patients recovering from illness or trauma-and 'high-protein' special diets or protein supplements to the ordinary diet are not infrequently prescribed for them. In the diets illustrated, only limited improvements could be expected from increasing the amount of protein, without regard to the dietary intake as a whole; the prescription of a 'high-protein' diet would not be effective unless the total calorie intake were to be increased to match it. This does not always appear to be appreciated.

In one hospital, 'high-protein' diets were supposed to provide a total of over $120 \mathrm{~g}$ 
protein, with as high energy intake as could be given, but often very ill patients who were given 'high-protein' diets could not eat very much, and it was doubtful if the protein could be fully utilized. The dietician at this hospital said that sometimes interns telephoned asking for diets containing $200 \mathrm{~g}$ protein, and had occasionally boasted that they had been able to 'put 200 or $300 \mathrm{~g}$ of protein into children in the burns unit'. A 'high-protein' diet sampled over $24 \mathrm{~h}$ at this hospital had been given to a woman aged 60 years who was very ill. The energy value was I $50 \mathrm{kcal}$ with $45 \mathrm{~g}$ protein or $15.6 \mathrm{PCal} \%$; the total intake was equivalent to $95 \%$ of estimated basal metabolism. Another 'high-protein' diet had been prescribed for a patient with suspected malignant disease who had been losing weight, with a history of increasing pain and loss of appetite. During $24 \mathrm{~h}$ her dietary intake had an energy value of $1262 \mathrm{kcal}$ with $52 \cdot 2 \mathrm{~g}$ protein or $16 \cdot 5 \mathrm{PCal} \%$.

In these 'high-protein' diets the concentration of dietary protein was high, but the protein value was subjected to calorie restriction owing to the patients' poor appetites, so the effective NDpCal \% was low. A diet with the concentration of protein usually found in 'ordinary' diet would serve as well as a 'high-protein' diet. There would appear to be no advantage in attempting to raise the concentration of protein or the total weight of protein above that found in a normal tiet until considerably higher calorie intakes are possible-more than twice the estimated basal metabolism.

In a burns unit, a 'high-protein' fluid diet for tube-feeding contained a mixture of eggs, milk, casein and sugar. The feed as prescribed would supply $3000 \mathrm{kcal}$ with $270 \mathrm{~g}$ protein-a protein concentration of $36 \mathrm{PCal} \%$. This protein concentration is unnecessarily high, for at concentrations above $27 \mathrm{PCal} \%$ it has been shown that the predicted NDpCal \% tends to fall (Miller \& Payne, I $101 \mathrm{I} a$ ). The predicted value of this food was $10.2 \mathrm{NDpCal} \%$-a value that could be obtained from a feed with no more than $18 \mathrm{PCal} \%$ of protein having the same prote:n score. But if given to a man with a basal metabolism of $1500 \mathrm{kcal} / 24 \mathrm{~h}$, the feed would be equivalent to $200 \%$ of basal metabolism, and because protein would be used for energy purposes the effective protein value as corrected for calorie restriction would be $8.5 \mathrm{NDpCal} \%$. No doubt the results obtained with the feed would be satisfactory, but they might be equally satisfactory, or might with some patients be improved, if the concentration of protein were reduced, and the calorie intake increased.

Concentrated protein foods such as Casilan (Glaxo Laboratories Ltd) can be found in the ward kitchens of many geriatric wards; in one hospital we asked how it was administered, and the nurse told us that when orderec it was usually sprinkled from a teaspoon over the rice pudding. Used in this way, it would seem to be no more useful than the Parrish's Food which would have been ordered in similar circumstances 50 years ago. Discussing nutritional needs of the aged, Higgons (19.59) stated: 'Increasing the dietary protein intake by the use of protein supplements does not as a rule have any profound effect upon the circulating blood proteins. Feeding experiments, however, indicate that caloric balance of the dist is of great importance to the proper utilization of nutrients.'

In the Minnesota experiment (Keys et al. 1950) young men who had suffered a $25 \%$ weight loss were rehabilitated at various calorie levels, averaging $2900 \mathrm{kcal} /$ day. 
It was found that a protein supplement of $25 \%$ or more to a protein intake already at a good level of 75-100 g/day had no real beneficial influence. 'This can be considered a "caloric restriction" in the rehabilitation period as demonstrated by the fact that men receiving 2100-2400 Calories per day did better than those on smaller quantities' (Keys et al. 1950). Even those receiving $3000 \mathrm{kcal}$ and over did better on still higher calorie intakes.

In the treatment of children suffering from kwashiorkor it has been shown that very high protein intakes, with high protein concentrations of $45.4 \mathrm{PCal} \%$ from skim milk fortified with casein, have no therapeutic advantage over skim milk alone, with $39.4 \mathrm{PCal} \%$ (Walt \& Hathorn, I960), and protein-deficient children are successfully treated with much lower concentrations of protein than this. Waterlow (196r) found that, in Jamaican infants recovering from protein malnutrition, the rate of weight gain depended more closely on the intake of calories than of protein. During recovery from protein malnutrition the daily calorie requirement might be as high as $150 \mathrm{kcal} / \mathrm{kg}$ body-weight, but a daily protein intake of $3-4 \mathrm{~g} / \mathrm{kg}(=$ approx. Io PCal \%) was found to be adequate.

In a recent paper (Graham, Cordano \& Baertl, 1963 ) it was stated that the emphasis on protein deficiency as the major cause of marasmus and kwashiorkor has meant that these diseases have often been treated with very high protein intakes but grossly inadequate calorie intakes. Attempts to improve the nutrition of such protein-depleted children by the administration of 'high-protein' supplements once a day without regard to calorie requirements were wasteful and inefficient.

The results of this study of food taken in British hospitals suggest that there may be a similar tendency for attention to be concentrated on the patients' requirements for protein (which are rightly considered to be important) without sufficient regard for the balance of the diet as a whole. This failure to take notice of all factors in the dietary was also illustrated in the report Food in Hospitals by the demonstration that younger patients who had the highest energy requirements and the highest calorie intakes also took a higher proportion of their total calorie intake in the form of patients' extras than did older patients with lower requirements. These additions to hospital food usually supplied sweet confectionery or fruit with a negligible protein content, thus reducing the $\mathrm{PCal} \%$ of the whole dietary.

The provision of $5 \circ \mathrm{g}$ reference protein/day for a $\mathrm{FAO}$ reference man (FAO, 1957a) weighing $65 \mathrm{~kg}$ with a basal metabolism of $1500 \mathrm{kcal} / 24 \mathrm{~h}$ would allow approximately $17 \mathrm{~g} /$ day above the maintenance requirement for the additional protein required to make good his losses. This is equivalent to $33 \mathrm{mg}$ reference protein (or net dietary protein) per basal metabolic kcal, or $7.5 \mathrm{NDpCal} \%$ at a minimum calorie allowance of $180 \%$ basal metabolism (cf. the average calorie intake of $178 \% \pm 4.2 \%$ (SE) taken by recuperating patients in the survey).

The curve of equation I (the correction needed for caloric restriction shown as the line $A B$ in Fig. I) has been drawn in Fig. 2 for crude proteins with scores 65,75 and 85. Fig. 2 shows the maximum effective weight of reference protein (or net dietary protein) which may be derived from any given calorie intake, and the approximate minimum values of $\mathrm{PCal} \%$ required to obtain any desired value of reference 
protein may be determined by reference to the curves drawn for different protein scores.

In practical terms for British hospital diets with a protein score of $75^{-80}$, it can be seen from Fig. 2 that improvements in protein value will generally be achieved by increases in the calorie value of the diet as a whole, and not ty raising protein concentration by a disproportionate increase in the weight of dietary protein while failing to match this increase with a rise in calorie intake. Satisfactory and appetizing meals taken in hospitals have $15-20 \mathrm{PCal} \%$; in general the most acceptable and appetizing meals have the highest concentrations of protein. If the diet as a whole (main meals and extras) still has a protein concentration of about $14 \mathrm{PCal} \%$, the protein values

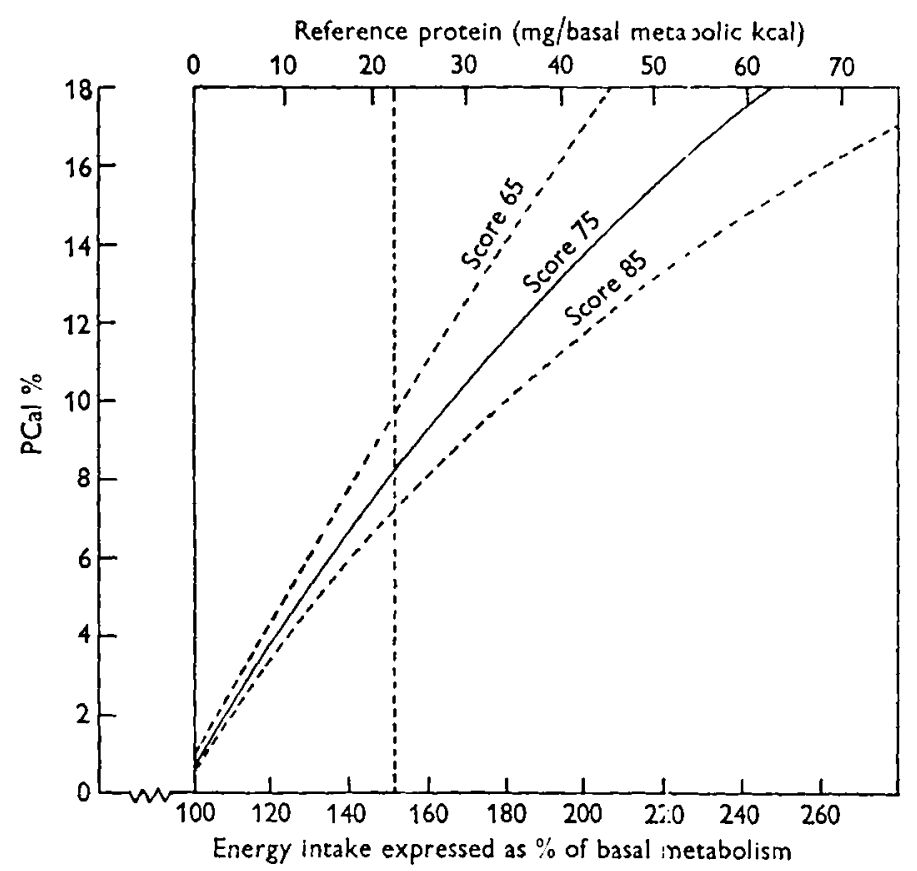

Fig. 2. The curve for energy restriction $(A B$ in Fig. $\mathrm{x}$ ) is drawn for crude dietary proteins with scores 65,75 and 85 . The weights of reference protein per basal metabolic kcal are the maximum effective values that can be obtained in accordance with equation I (p. 557) at given energy intakes. The curves for each protein score indicate the minimun values of $\mathrm{PCal} \%$ required to attain these maximum effective values of reference protein per basal metabolic kcal.

should be entirely satisfactory at appropriate calorie intakes up to $200 \%$ of basal metabolic requirements. Up to this level of calorie intake, increases of concentration of protein would not be expected to raise protein values; increases of calorie intake while protein concentration is maintained would do so. Higher requirements could be met either by raising calorie intake still further while maintaining concentration, or also at intakes above $200 \%$ of basal metabolism by raising protein concentration. In practical hospital dietetics the highest attainable protein value would appear to be given by a diet containing $18-20 \mathrm{PCal} \%$ with an energy value of $250 \%$ of basal metabolism. What these recommendations mean in terms of calories and quantity of protein per day is shown in Table 3 . 
Table 3. Recommended allowances for maintenance and recuperative diets

\begin{tabular}{|c|c|c|c|c|c|c|c|c|}
\hline \multirow{2}{*}{$\begin{array}{l}\text { Estimated } \\
\text { basal metabolism } \\
\text { (kcal/day) }\end{array}$} & \multicolumn{2}{|c|}{$\begin{array}{c}\leftarrow \text { Maintenance } \rightarrow \\
\text { 150\% basal, } \\
\text { I4 PCal \% }\end{array}$} & \multicolumn{2}{|c|}{$\begin{array}{l}\text { I80\% basal, } \\
\text { I4 PCal \% }\end{array}$} & \multicolumn{2}{|c|}{$\begin{array}{c}\text { - Recuperative } \\
200 \% \text { basal, } \\
\text { } 44 \mathrm{PCal} \mathrm{\%}\end{array}$} & \multicolumn{2}{|c|}{$\begin{array}{l}250 \% \text { basal, } \\
18 \mathrm{PCal} \%\end{array}$} \\
\hline & $\begin{array}{l}\text { Energy } \\
(\mathrm{kcal})\end{array}$ & $\begin{array}{l}\text { Protein } \\
\text { (g) }\end{array}$ & $\begin{array}{l}\text { Energy } \\
\text { (kcal) }\end{array}$ & $\begin{array}{l}\text { Protein } \\
\text { (g) }\end{array}$ & $\begin{array}{c}\text { Energy } \\
\text { (kcal) }\end{array}$ & $\begin{array}{l}\text { Protein } \\
\text { (g) }\end{array}$ & $\begin{array}{r}\text { Energy } \\
\text { (kcal) }\end{array}$ & $\begin{array}{l}\text { Protein } \\
\quad(\mathrm{g})\end{array}$ \\
\hline 1000 & 1500 & 53 & 1800 & 63 & 2000 & 70 & 2500 & 113 \\
\hline I100 & 1650 & 58 & 1980 & 70 & 2200 & 77 & 2750 & 126 \\
\hline I 200 & 1800 & 63 & 2160 & 76 & 2400 & 84 & 3000 & 135 \\
\hline 1300 & 1950 & 68 & 2320 & $8 \mathrm{I}$ & 2600 & 91 & 3250 & 147 \\
\hline 1400 & 2100 & 74 & 2520 & 88 & 2800 & 98 & 3500 & $\begin{array}{r}158 \\
\end{array}$ \\
\hline 1500 & 2250 & 79 & 2700 & 95 & 3000 & 105 & 3750 & 169 \\
\hline 1700 & 2550 & 90 & 3060 & 107 & 3400 & 119 & 4250 & I9I \\
\hline
\end{tabular}

Protein values are calculated for a protein score of 75 . The mean NPU (standardized) of nineteen bulked meals derived from our 500 samples of hospital meals was $77 \cdot 5 \pm 7 \cdot 0$ (sD).

A reference man age 25 years weighs $65 \mathrm{~kg}$ and has a basal metabolism of $1500 \mathrm{kcal} / \mathrm{day}$; a reference woman aged 25 years weighs $55 \mathrm{~kg}$ and has a basal metabolism of $1260 \mathrm{kcal} / \mathrm{day}$ (FAO, 1957a).

The protein values determined by the methods described in this paper do not necessarily show the use that was made of dietary protein by the patients whose diets were sampled. They predict the utilization of protein by young growing animals with a high $\mathrm{N}$ demand, which would be expected from the same dietary intake, and the values therefore indicate the maximum potential of the diet. They would never be more, they might perhaps be less. Not all consumers would have similar demands for $\mathrm{N}$, and utilization of protein could fall short of the predicted potential. The values are intended to show the best that could be expected from a diet, and how higher demands for $\mathrm{N}$ could best be met.

This paper is concerned with the food taken by patients receiving ordinary hospital food without prescribed dietary restrictions or modifications required in the treatment of particular diseases. It is not, for example, concerned with low-calorie diets prescribed for obesity, in which the patient's own resources of stored energy would be mobilized, and the equation governing calorie restriction would be modified.

\section{SUMMARY}

I. The protein-calorie values of the $24 \mathrm{~h}$ dietary intake of eighty-seven weighed patients who were not overweight were determined. Calorie intake was expressed as the percentage of estimated basal metabolic requirements, protein intake as net dietary protein calories $\%$ or effective reference protein calories $\%$, a factor which takes into account both the concentration of protein in the diet and protein quality. The methods used in these assessments are described.

2. In British hospital diets there is usually a high concentration of good-quality protein derived from mixed sources. The factor governing protein values is usually the total calorie intake, and not the weight of protein taken by the patient. Improvement of the protein value of the diet, when it may be in the patient's interest, can best be obtained by maintaining a concentration of ${ }_{14} \mathrm{PCal} \%$ in the whole dietary intake 
and by raising calorie intake. Increases of protein concentration above this level are likely to be effective (except for obese patients) only at high calorie intakes exceeding $200 \%$ of basal metabolism.

\section{REFEREN CES}

Association of Official Agricultural Chemists (1960). Official Metho.ls of Analysis, gth ed. Washington, DC: Association of Official Agricuitural Chemists.

Beattie, J., Herbert, P. H. \& Bell, D. J. (1947). Brit. F. Nutr. I, 2 22.

Benditt, E. P., Humphreys, E. M., Wissler, R. W., Steffee, C. H., Fræzier, L. E. \& Cannon, P. R. (1948). F. Lab. clin. Med. 33, 257.

Calloway, D. H. \& Spector, H. (1954). Amer. F. clin. Nutr. 2, 405.

Calloway, D. H. \& Spector, H. (1955). F. Nutr. 56, 533.

FAO (1957a). F.A.O. nutr. Stud. no. I5.

FAO (1957b). F.A.O. nutr. Stud. no. 16.

Graham, G. G., Cordano, A. \& Baertl, J. M. (1963). Y. Nutr. 81, 249.

Higgons, R. A. (1959). In Protein and Amino Acid Nutrition, p. 507. [A. A. Albanese, editor.] New York and London: Academic Press Inc.

Keys, A., Brožek, J., Henschel, A., Michelsen, O. \& Taylor, H. L. (x950). The Biology of Human Starvation. Minneapolis: University of Minnesota Press.

Metropolitan Life Assurance Company (1959). Statist. Bull. Metrop. Life Insce Co. 401, I.

Miller, D. S. \& Donoso, G. (1963). F. Sci. Fd Agric. 14, 345.

Miller, D. S. \& Payne, P. R. (1959). Brit. F. Nutr. 13, 501.

Miller, D. S. \& Payne, P. R. (1961a). Brit. F. Nutr. 15, I1.

Miller, D. S. \& Payne, P. R. (1961 b). F. Nutr. 75, 225.

Miller, D. S. \& Payne, P. R. (1962). F. Nutr. 78, 255.

Miller, D. S. \& Payne, P. R. (1964). Proc. Nutr. Soc. 23, Ir.

National Research Council (1963). Protein Quality Evaluation. Publ. nat. Res. Coun., Wash., no. I Ioo, Section III, p. 29 .

Pellett, P. I. \& Eddy, T. P. (1964). Brit. F. Nutr. x8, 567.

Platt, B. S., Eddy, T. P. \& Pellett, P. L. (1963). Food in Hospitals. London: Oxford University Press, for Nuffield Provincial Hospitals Trust.

Platt, B. S., Miller, D. S. \& Payne, P. R. (1961). In Recent Adiances in Human Nutrition, p. 351. [J. F. Brock, editor.] London: Churchill.

Robertson, J. D. \& Reid, D. D. (1952). Lancet, i, 940.

Rose, W. C., Haines, W. J. \& Warner, D. T. (1954). F. biol. Chem. 206, 42 I.

Swanson, P. (1959). In Protein and Amino Acid Nutrition, p. 195. [A. A. Albanese, editor.] New York and I ondon: Academic Press Inc.

Walt, F. \& Hathorn, M. (1960). Arch. Dis. Childh. 35, 455.

Waterlow, J. C. (1961). F. trop. Pediat. 7, 16. 